\title{
VLOGA NARAVNOGEOGRAFSKIH ZNAČILNOSTI POREČJA PRI SONARAVNEM UPRAVLJANJU Z VODNIMI VIRI V POREČJU KAMNIŠKE BISTRICE
}

\author{
Valentina Brečko Grubar \\ Fakulteta za humanistične študije Koper Univerze na Primorskem, \\ Glagoljaška 8, SI - 6000 Koper, Slovenija \\ e-mail: valentina.brecko.grubar@fhs.upr.si
}

Izvirni znanstveni članek

COBISS 1.01

\section{Izvleček}

Prispevek obravnava naravnogeografske značilnosti porečja Kamniške Bistrice in njihov pomen za sonaravno upravljanje $\mathrm{z}$ vodnimi viri. V porečju Kamniške Bistrice so prisotni različni vodni viri, ki skupaj predstavljajo veliko količino vode. Znotraj porečja Kamniške Bistrice so velike razlike med naravnogeografskimi značilnostmi posameznih delov porečja, ki jih prispevek obravnava v odnosu do značilnosti vodnih virov.

Ključne besede: sonaravno upravljanje z vodnimi viri, porečje, Kamniška Bistrica.

\section{THE ROLE OF NATURAL-GEOGRAPHICAL CHARACTERISTICS OF THE DRAINAGE BASIN IN THE SUSTAINABLE MANAGEMENT OF WATER RESOURCES IN THE KAMNIŠKA BISTRICA DRAINAGE BASIN}

\begin{abstract}
The paper discusses natural-geographical characteristics of the Kamniška Bistrica drainage basin and their influence of water resources. Different water resources occur in the Kamniška Bistrica drainage basin, which all together represent a large amount of water. Great differences exist within the Kamniška Bistrica drainage basin between the naturalgeographical characteristics of its sections, which are discussed in the paper in relation to the characteristics of water resources.
\end{abstract}

Key words: sustainable management of water resources, drainage basin, Kamniška Bistrica. 


\section{UVOD}

Sonaravno upravljanje z vodnimi viri razumemo kot usmeritev pri gospodarjenju $\mathrm{z}$ vodnimi viri, ki bo zagotavljala trajno oskrbo s kakovostno vodo ter omogočala obstoj in delovanje ekosistemov, ključnih za ohranjanje kakovosti okolja in še posebej vodnih virov. Porečje je, po našem mnenju, primerna prostorska enota za gospodarjenje z vodnimi viri, saj predstavlja celoto, katere sestavni deli so medsebojno povezane površinske in podzemne vode, hkrati pa je to območje, kjer pokrajinska raba odločilno vpliva na količinsko in kakovostno obnavljanje vodnih virov. V Sloveniji, zlasti v njenem alpskem in predalpskem delu, so vodni viri količinsko bogati, zato se pri upravljanju z njimi v ospredje postavlja skrb za varovanje pred onesnaževanjem okolja in ohranjanje dobre kakovosti vode. Trajno rabo vodnih virov je mogoče zagotoviti z vzpostavljenim ravnovesjem med varovanjem okolja in pokrajinsko rabo, ob upoštevanju naravnogeografskih oziroma hidrogeografskih značilnosti porečja, ki vplivajo na pokrajinsko občutljivost okolja vodnih virov. Sonaravno upravljanje z vodnimi viri bi zato moralo v največji možni meri upoštevati značilnosti porečja. V preteklosti so bile pogosto zapostavljene tako pokrajinske značilnosti kot tudi posledice preteklih posegov človeka v okolje. Urejanje vodnih tokov, raba vodnih virov in drugi posegi v porečjih so se načrtovali in izvajali sektorsko, posledice pa so se pogosto pokazale šele kasneje.

$\mathrm{K}$ upoštevanju načel trajnosti in sonaravnosti pri gospodarjenju $\mathrm{z}$ okoljskimi viri nas zavezujejo mednarodno sprejete strategije varstva okolja in narave, konvencije in protokoli, katerih podpisnica je Slovenija ter lastni program varstva okolja in dokumenti, ki iz njega izhajajo. Krovni dokument urejanja področja voda v Sloveniji, to je Zakon o vodah (2002), navaja kot cilj upravljanja $\mathrm{z}$ vodami ter vodnimi in priobalnimi zemljišči doseganje dobrega stanja voda in drugih z vodami povezanih ekosistemov, zagotavljanje varstva pred škodljivim delovanjem voda, ohranjanje in uravnavanje vodnih količin in spodbujanje trajnostne rabe voda, ki omogoča različne vrste rabe voda, ob upoštevanju dolgoročnega varstva razpoložljivih vodnih virov in njihove kakovosti. Med načeli upravljanja z vodami sta kot prva navedena: načelo celovitosti, ki upošteva naravne procese in dinamiko voda ter medsebojno povezanost in soodvisnost vodnih in obvodnih ekosistemov na območju povodja ter načelo dolgoročnega varstva kakovosti in smotrne rabe razpoložljivih vodnih virov (Zakon..., 2002).

V porečju Kamniške Bistrice sta, tako kot v številnih porečjih, pokrajinska raba in raba vodnih virov povzročili trajne spremembe odtočnih značilnosti in povečali pokrajinsko občutljivost okolja vodnih virov, prekomerno obremenjevanje okolja pa je vzrok onesnaženosti nekaterih pomembnih vodnih virov. Kot enega pomembnejših ciljev sonaravno zasnovanega upravljanja z vodnimi viri v porečju Kamniške Bistrice vidimo zmanjšanje obremenjevanja okolja na raven, ki je sprejemljiva glede na samočistilno zmogljivost okolja. S tem bi bili dani pogoji za izboljšanje kakovosti najpomembnejšega podzemnega vodnega vira, to je podtalnice na Kamniškobistriški ravnini in spodnjega toka reke Kamniške Bistrice. 


\section{POREČJA KOT PROSTORSKE ENOTE ZA SONARAVNO UPRAVLJANJE Z VODNIMI VIRI}

Po definiciji je porečje ozemlje, obdano z razvodnico, ki oddaja vodo v posamezno reko (Radinja, 1999) oziroma je celotna površina, s katere se stekajo, površinsko ali podzemeljsko, padavine v rečni sistem (Plut, 2000). Porečje je odprt pokrajinski (morfološki) sistem odvisen od vnosov, prenosov in iznosov energije in snovi. Najpomembnejši so: vnos sončne energije in padavin, prenosi med sloji rastlinstva, površjem, prstjo, kamninami ter iznosi vode $\mathrm{v}$ obliki vodnega odtoka in izhlapevanja (Petts, Braward, 1996). Porečje, povodje, vodozbirno zaledje s svojo sestavo, sestavnimi deli ali s posameznimi elementi omogočajo proučevanje delovanja ter kvantitativni prikaz hidroloških pojavov in procesov. Medsebojna povezanost in odvisnost vode in dejavnikov okolja v porečju je izjemno velika in vsestranska. $Z$ vidika odtočnih razmer, rečnega režima in vodnih virov so pomembne značilnosti porečja: površina porečja, razvodnica, razvodje, oblika porečja, simetrija porečja, gozdnatost, najvišja in najnižja točka, povprečni strmec porečja, gostota rečne mreže, klasifikacija tekočih voda in specifični odtok (Plut, 2000).

Najpomembnejši dinamični proces v porečju je vodni odtok, ki v širšem pomenu obsega vse oblike voda od padavin do odtoka vode v drugo reko. Obsega padavine, zadrže-vanje padavin (intercepcijo) v vegetacijski odeji in na neporaslem površju, padavine, ki so dosegle prst oziroma kamninsko podlago brez prsti, površinske odtoke (odtok v rečni mreži, površinski odtok na pobočjih brez rečne mreže, odtok pod površjem skozi sloj prsti ali kamnin) in podzemne odtoke (tok podzemne vode $\mathrm{v}$ zasičeni plasti in tokove v prezračeni coni). $Z$ vidika vodnih virov je ključnega pomena vodni odtok, ki odraža količino, obliko in razporeditev padavin, učinke temperaturnih razmer, kamninske sestave (prepustnost in vodna kapaciteta kamnin), reliefa (naklon pobočij), prsti (infiltracijska kapaciteta), vegetacije (gozdnatosti) in drugih naravnih in antropogenih sestavin porečja, zato je zelo spremenljiv. Izrazimo ga s pomočjo naslednjih ključnih kvantitativnih kazalcev: pretok vode, specifični odtok, višina odtoka in odtočni količnik (Plut, 2000). Pri upravljanju z vodnimi viri je pomemben kazalec vodna bilanca porečja in rezultat le te, to je sprememba vodnih zalog.

Gospodarjenje oziroma upravljanje z vodnimi viri v Sloveniji je zasnovano na prostorskih enotah, kot so vodna območja, porečja oziroma povodja. »Teritorialne podlage upravljanja $\mathrm{V}$ Republiki Sloveniji temeljijo na naravno potekajočih hidrografskih mejah povodij in porečij in kot osnovno teritorialno-administrativno delitev določajo dve vodni območji: vodno območje Donave, ki se deli na porečja reke Mure, Drave in Save, ter vodno območje Jadranskega morja, ki se deli na povodje reke Soče ter povodje jadranskih rek z obalnim morjem « (Nacionalni..., 1999). Skladno s sprejetimi dokumenti bo v prihodnje upravljanje z vodami temeljilo na Načrtih upravljanja z vodami, kjer bodo, na osnovi lastnosti vodnih območij ter stanja, opredeljeni cilji upravljanja glede varstva voda, urejanja voda in rabe voda. Izdelavi načrtov upravljanja z vodami na vodnem območju Donave in vodnem območju Jadranskega morja do leta 2009 bodo sledili podrobnejši načrti upravljanja z vodami. Načrti upravljanja z vodami morajo biti upoštevani oziroma povezani s prostorskimi akti in sektorskimi načrti, kadar bi le ti lahko vplivali na varstvo voda, njihovo urejanje in rabo (Zakon..., 2002). 


\section{GEOGRAFSKE ZNAČILNOSTI POREČJA KAMNIŠKE BISTRICE}

Površina porečja Kamniške Bistrice obsega $534,4 \mathrm{~km}^{2}$ reliefno razgibanega ozemlja med Ljubljanskim poljem na jugu in Kamniško-Savinjskimi Alpami na severu. Meje porečja so večinoma lahko določljive topografske razvodnice, izjema so le razvodnice med območji podtalnic Kamniškobistriške ravnine, Kranjskega polja in Ljubljanskega polja. Na zakraselem delu porečja pa je bila z raziskavami določena hidrografska razvodnica. Zaradi posegov človeka $v$ rečno mrežo je meja porečja spremenjena $v$ skrajnem jugovzhodnem delu porečja, kjer je v mlinščico speljan nekdanji pritok Kamniške Bistrice, mlinščica pa se ne izliva nazaj v Kamniško Bistrico, ampak v Savo. Porečje Kamniške Bistrice meji na zahodu na porečje Kokre in na območje podtalnice Kranjskega polja, na vzhodu na porečje Savinje ter na jugu na porečje Save in območje podtalnice Ljubljanskega polja.

\section{Slika 1: Lega porečja Kamniške Bistrice}

Figure 1: Location of the Kamniška Bistrica drainage basin

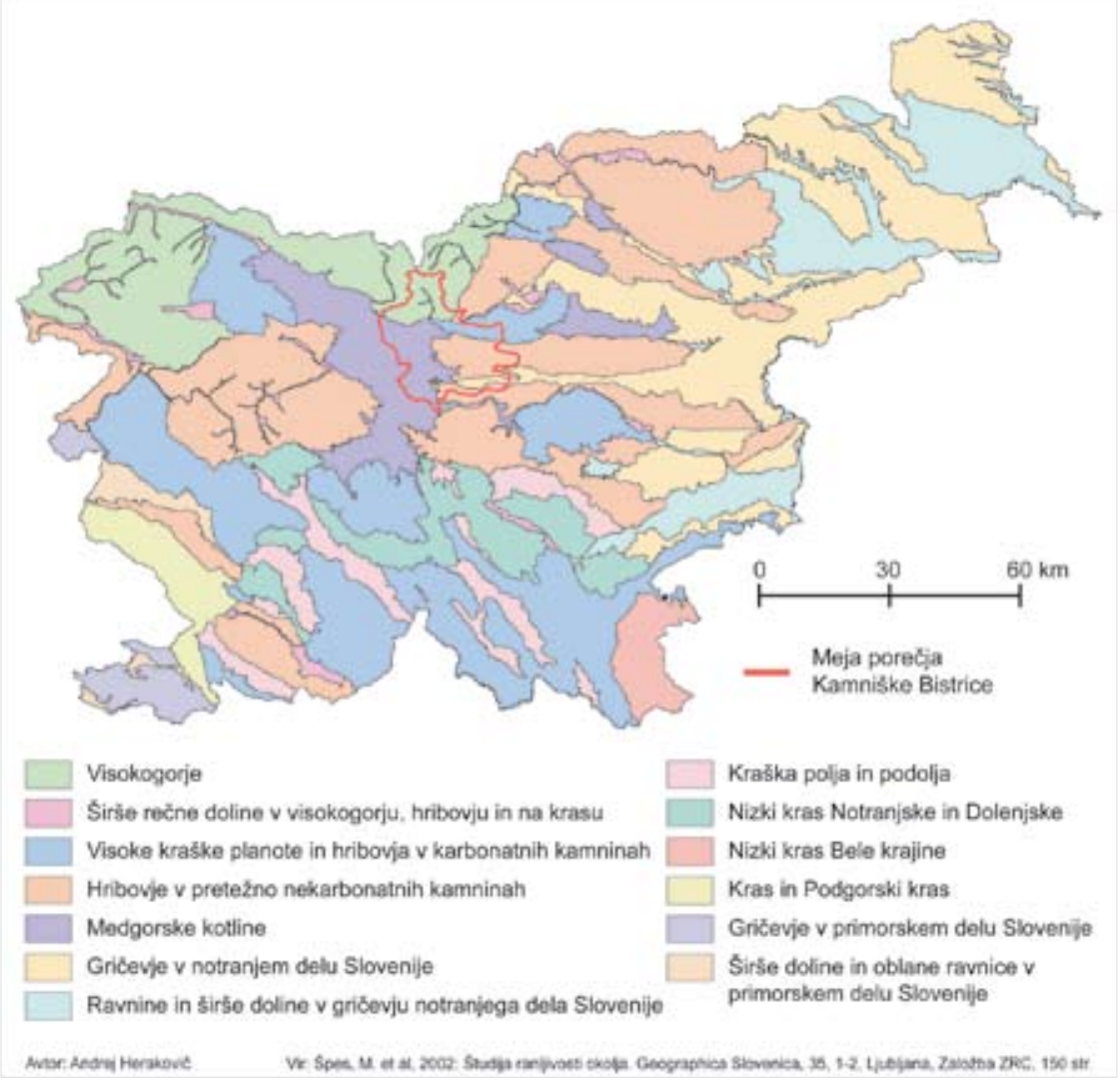


Kamniška Bistrica izvira v Koncu pod Grintavci, na nadmorski višini 600 m, kamor pritekajo podzemne vode iz obsežnega grebena Kamniško-Savinjskih Alp. Ob izdatnejših padavinah se jim v povirnem delu toka pridružijo še Studenci pod Mokrico, Mali izvir ter Kamniška Bela. Izpod Zvoha priteka kot desni pritok v Kamniško Bistrico hudourniška Korošica, nad Zgornjo Stahovico se v njo izliva pritok Grohat, ki izvira pod Kamniškim vrhom in pri Spodnji Stahovici pritok Bistričica, ki kot Blatnica izvira pod Krvavcem. Kot leva pritoka se v Kamniško Bistrico izlivata Konjska izpod Velike planine in pri Stahovici Črna z Volovljekom. V Kamniku se v Kamniško Bistrico izliva levi pritok Nevljica, ki zbira vode v Tuhinjski dolini in pri Domžalah se, prav tako kot levi pritok, izliva Rača s svojim največjim pritokom Radomljo. Pod Biščami se kot desni pritok v Kamniško Bistrico izliva del vode Pšate, ki je z razbremenilnim kanalom za visoke vode s Kamniško Bistrico povezana že nad Domžalami, del njene vode pa je pred izlivom speljane v mlinščico Pšate. Dolžina Kamniške Bistrice od izvira na vznožju Kamniško-Savinjskih Alp do izliva v Savo vzhodno od Ljubljane je $32 \mathrm{~km}$, od izvira na pobočju do izliva pa 38,2 km (Vodnogospodarska..., 2002).

Porečje Kamniške Bistrice sestavljajo tri večja in več manjših porečij njenih pritokov. Večja porečja imajo pritoki Nevljica, Rača z Radomljo in Pšata, manjša pa Kamniška Bela, Korošica, Grohat, Bistričica in Črna. Površina porečja Kamniške Bistrice nad vodomerno postajo Kamnik I obsega 195 km² (Vodnogospodarske..., 2002). Porečje Kamniške Bistrice pod navedeno vodomerno postajo sestavljajo: porečje Rače z Radomljo, ki obsega 164,5 km² levega dela ter porečje Pšate $\mathrm{s} 147,9 \mathrm{~km}^{2}$ in Kamniškobistriška ravnina s približno $28 \mathrm{~km}^{2}$ na njegovem desnem delu. Porečji Rače z Radomljo in Pšate predstavljata skoraj dve tretjini celotnega porečja. Delujoče vodomerne postaje v porečju so: Nevlje na Nevljici, Podrečje na Rači, Suhadole, Topole in Trzin na Pšati, Kamnik I in Vir na Kamniški Bistrici ter na mlinščici v Domžalah (Hidrološki..., 2006).

Porečje je notranje precej raznoliko. Povirni del in desna stran zgornjega dela porečja pripadata gorovju s slemeni, vrhovi in kraškimi podi, leva stran zgornjega dela pa visoki planoti s kraškimi jamami in brezni. Ledeniška dolina Kamniške Bistrice se zaključuje s čelno moreno pri Stahovici. V tem delu porečja prevladujejo nadmorske višine med 600 in $2000 \mathrm{~m}$, vertikalna razčlenjenost reliefa je izjemno velika, prav tako nakloni pobočij. Južno od naselja Stahovica gorovje prehaja v hribovje in prevladujejo nadmorske višine pod $1000 \mathrm{~m}$. Nad to nadmorsko višino se dviguje le Menina planina. Reliefna enota hribovje obsega levo stran porečja Nevljice in domala celotno porečje Rače z Radomljo. Dolinsko dno Nevljice je široko, prav tako Rače, dolinsko dno Radomlje pa je večinoma ozko. Prevladujeta rečni erozijsko-denudacijski relief in velika horizontalna razčlenjenost. Gričevja je v porečju malo. Ta reliefna enota obsega Tunjiško gričevje, to je levo stran zgornjega dela porečja Pšate in osamelce na obrobju spodnjega dela porečja Kamniške Bistrice. Na desni strani, v jugozahodnem in v južnem delu porečja prevladuje akumulacijski relief, ki je malo razčlenjen. Prevladujejo nadmorske višine pod $400 \mathrm{~m}$ in površje se enakomerno znižuje v smeri izliva reke. Ravnina z rečnimi terasami in obrečnimi ravnicami obsega spodnje dele porečij Pšate in Rače ter območje Homškega, Mengeškega in Domžalskega polja (Geografski..., 1998). Porečje Kamniške Bistrice ima zelo visok indeks reliefa ali reliefno amplitudo, ki znaša 1986 m. Najvišja točka v porečju je Grintavec z 2558 m nadmorske višine, najnižja točka pri izlivu 
Kamniške Bistrice v Savo pa je na 264 m nadmorske višine. Med porečji pritokov Kamniške Bistrice imajo najvišji indeks reliefa porečja Pšate (1590 m), Nevljice (1133 m) in Črne (1065 $\mathrm{m})$, nižjega ima porečje Radomlje (652 m) in še nižjega porečje Rače brez Radomlje (531 m). Povprečni nakloni v porečju presegajo $70 \%$ v zgornjem delu porečja do izliva Korošice, od tod do izliva Črne pri Stahovici znašajo nad 60 \%, do izliva Nevljice v Kamniku nad 50 \%, do izliva Rače pod Domžalami nad 40 \%, do izliva Pšate nad $30 \%$ in do izliva v Savo nad $26 \%$ (Vodnogospodarska..., 2002).

Slika 2: Porečje Kamniške Bistrice s porečji večjih pritokov in vodomernimi postajami

Figure 2: The Kamniška Bistrica drainage basin with the drainage basins of its bigger tributaries and water-gauging posts

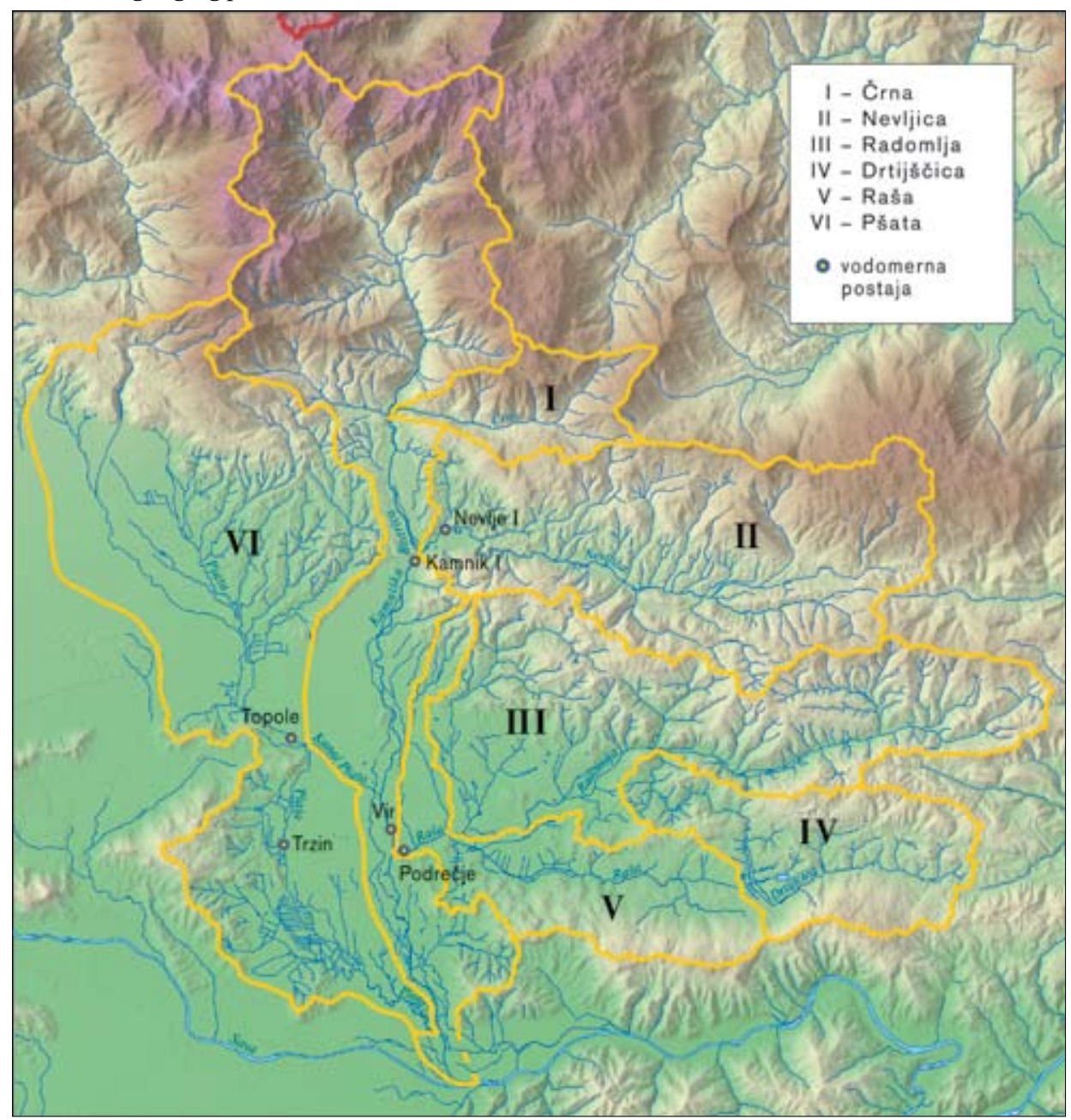


V zgornjem delu porečja Kamniške Bistrice, v porečjih Črne in Bistričice ter v povirnem delu porečja Pšate in njenega pritoka Reke, ki segata na območje Krvavca prevladujejo karbonatne kamnine, apnenec in dolomit triasne starosti. Podobne kamnine gradijo levi del porečja Nevljice, desnega pa različne miocenske kamnine. Tudi v Tunjiškem gričevju prevladujejo pesek, peščenjak, glina, melj, prod, konglomerat in lapor miocenske starosti. Ob Pšati in njenih pritokih s Tunjiškega gričevja prevladujejo glinasti prod, peščena glina in glina, zahodno od Suhadol pa se pojavi prodni zasip Kranjskega polja. V porečju Radomlje je kamninska zgradba zelo pestra. Na območju Črnega grabna, v spodnjem delu porečja Drtijščice ter nekaterih desnih pritokov Radomlje so v večjem obsegu zastopani permokarbonski glinasti skrilavci in kremenovi peščenjaki, v manjšem obsegu se pojavlja triasni dolomit, v dnu doline pa je črni ali karbonski prod. Od Lukovice do Doba prevladujejo glinasti prod, peščena glina in glina kvartarne starosti ter pliocenski glina, melj in ilovica. V porečjih Hudskega potoka, Rovščice in Želodnika najdemo še ledenodobne usedline. V porečjih Drtijščice in Rače so zastopane miocenske sedimentne kamnine, podobne flišu in slabo prepustni kvartarni rečni nanosi. Kamninska zgradba večine levega dela porečja Kamniške Bistrice omogoča prevladujoč površinski odtok padavin. Južno od Kamnika, skoraj na celotni desni strani porečja ter v ožjem pasu vzdolž toka Kamniške Bistrice na levi strani, prevladujejo različno zrnate sedimentne kamnine, ki sta jih odložili Kamniška Bistrica in Pšata s pritoki. Večinoma so dobro prepustne in porozne, kar je pomembno za nastanek zalog podtalnice v jugozahodnem delu porečja. Ob Pšati so na površini v večji meri zastopani slabo prepustni glineno-ilovnati sedimenti. Na obrobju južnega dela porečja se nahajajo poleg skrilavih peščenjakov in glinovcev tudi apnenci, ki gradijo osamelce in gričevje, po katerem poteka razvodnica med Savo in Kamniško Bistrico (Osnovna..., 1982).

Pri podnebnih značilnostih se razlike kažejo v količini padavin, v trajanju snežne odeje in v letnem poteku temperatur. V porečju Kamniške Bistrice je deset meteoroloških postaj, ki merijo količino padavin. Podatki kažejo na precejšnje razlike v namočenosti znotraj porečja. V obdobju 1961-1990 je srednja letna količina padavin v Kamniški Bistrici znašala 2158 mm, na Črnivcu 1656 mm in na Krvavcu 1502 mm (Kolbezen idr., 1998). Navedene padavinske postaje kažejo količino padavin v zgornjem delu porečja Kamniške Bistrice. V hribovitem delu porečja kažejo povprečno količino padavin podatki za naslednje padavinske postaje: Ambrož pod Krvavcem z izmerjeno količino 1572 mm, Zgornji Tuhinj z 1455 mm, Moravče z $1221 \mathrm{~mm}$, v bližini meje porečja Kamniške Bistrice v zahodnem delu je še padavinska postaja Cerklje z izmerjeno količino padavin $1487 \mathrm{~mm}$ ter v vzhodnem delu Šentgotard z $1330 \mathrm{~mm}$ padavin. V spodnjem delu porečja razpolagamo s podatki za padavinski postaji Volčji Potok in Depala vas. Na prvi je bilo v obdobju 1961-1990 izmerjeno $1396 \mathrm{~mm}$ in na drugi $1359 \mathrm{~mm}$. Korigirane vrednosti količine padavin glede na vodni odtok so bile pri vseh padavinskih postajah višje, na Krvavcu za več kot 300 mm (Kolbezen idr., 1998). Povprečna količina padavin v porečju izračunana na osnovi podatkov vseh padavinskih postaj znaša $1513 \mathrm{~mm}$. Padavinska postaja Kamniška Bistrica se po številu dni z vsaj $1 \mathrm{~mm}$ padavin, po številu dni z vsaj $10 \mathrm{~mm}$ padavin in po številu dni z vsaj $20 \mathrm{~mm}$ padavin v obdobju 1971-2000 uvršča med postaje z najvišjimi vrednostmi v Sloveniji (Vodno..., 2003). Snežna odeja traja na Krvavcu okoli 160 dni in v Volčjem Potoku okoli 55 dni na leto. Srednja letna 
temperatura zraka na Krvavcu je $3{ }^{\circ} \mathrm{C}$, januarska je $-4,6^{\circ} \mathrm{C}$, julijska pa je $11,3^{\circ} \mathrm{C}$. Srednja letna temperatura zraka v Volčjem Potoku je $8,6^{\circ} \mathrm{C}$, januarska je $-2,3^{\circ} \mathrm{C}$, julijska pa je $18,6^{\circ} \mathrm{C}$ (Klimatografija..., 1995).

Gozdnatost porečja pomembno vpliva na površinski odtok padavin. Za porečje Kamniške Bistrice je značilna velika gozdnatost, ki po ocenah pridobljenih na osnovi topografskih kart v merilu $1: 25.000$ presega $60 \%$. Po podatkih o dejanski rabi zemljišč po letu 2000 je delež gozdnih površin v porečju 56,4 \% (Dejanska..., 2006). Delež gozdnih površin v porečju Kamniške Bistrice nad Kamnikom je $63 \%$, v porečjih Črne $85 \%$, Nevljice $65 \%$, Pšate 48 \%, Rače brez Radomlje 52 \% in Radomlje 56 \% (Državna..., 1996a; Državna..., 1996b; Državna..., 1996c; Državna..., 1996d; Državna..., 1998a; Državna..., 1998b; Državna..., 1998c; Državna..., 1998d). Po podatkih za katastrske občine je delež gozda v zgornjem delu porečja nad $50 \%$, v porečju Nevljice $63,5 \%$, Pšate 37,6 \%, Rače brez Radomlje $42 \%$ in Radomlje 48 \% (Kmetijska..., 1999). Na gozdnatost v zgornjem delu porečja vplivajo deli porečja, ki segajo nad zgornjo gozdno mejo. Ta se giblje med 1500 in 1700 m, ponekod pa skalna pobočja segajo tudi nižje. Malo gozdnih površin je na Kamniškobistriški ravnini, kjer so se ohranili le ostanki gozda ob vodnih tokovih in na vzpetem obrobju ravnine. Po podatkih o dejanski rabi kmetijskih zemljišč jih je pod $20 \%$ (Dejanska..., 2006). V ravninskem spodnjem delu porečja je bil gozd večinoma odstranjen zaradi kmetijske in urbane rabe zemljišč.

\section{FUNKCIJSKO VREDNOTENJE NARAVNOGEOGRAFSKIH ZNAČILNOSTI POREČJA KAMNIŠKE BISTRICE}

Razvitost porečij in njihova simetričnost sta odraz razvoja reliefa na širšem območju, ključno pa je ugrezanje Ljubljanske kotline, ki je pritegnilo vodne tokove z obrobja. Zaradi zniževanja dna kotline je imela Kamniška Bistrica velik strmec, s tem veliko erozijsko moč, kar je vplivalo na razvoj rečne mreže v porečju. Z zapolnjevanjem Ljubljanske kotline z rečnoledeniškimi nanosi se je strmec zmanjševal in s tem tudi transportna moč reke. Za porečje Kamniške Bistrice je značilna razmeroma dobra razvitost, razmerje med dolžino porečja in njegovo srednjo širino je 1,5:1. Med porečji pritokov Kamniške Bistrice je razmeroma dobro razvito porečje Rače z Radomljo in zgornji del porečja Pšate nad vodomerno postajo Moste, slabše razvita pa so ostala porečja. Porečje Kamniške Bistrice je asimetrično, s koeficientom asimetrije 0,1 . Površina desnega dela porečja meri $218 \mathrm{~km}^{2}$ in površina levega $332 \mathrm{~km}^{2}$. Zelo izrazito asimetrično porečje ima Rača, kjer porečje njenega pritoka Radomlje z Drtijščico predstavlja desno stran porečja Rače. Asimetrična so tudi porečja Radomlje, Nevljice in Črne, kjer so v vseh primerih večje desne strani porečij (Brečko Grubar, 2006). Z reliefom in kamninsko zgradbo so poleg izoblikovanosti porečja v veliki meri pogojene tudi značilnosti vodnih tokov. Vodni tok Kamniške Bistrice je zelo raven, kar je posledica že omenjenega ugrezanja Ljubljanske kotline in erozijske moči Save. Rečna mreža je, podobno kot porečje, asimetrična v levo zaradi prevladujočih neprepustnih kamnin v vzhodnem delu porečja. Tudi večina pritokov Kamniške Bistrice ima slabo razvit tok. Rečne mreže levih pritokov Kamniške 
Bistrice so vse izrazito asimetrične in pri večini je dolžina desnih pritokov večja v primerjavi z dolžino levih. Črna sploh nima levih pritokov, rečna mreža Nevljice je izrazito asimetrična s številčnejšimi in daljšimi desnimi pritoki, še izraziteje asimetrična pa je rečna mreža Rače, kjer Radomlja s svojimi pritoki predstavlja večino njene rečne mreže na desni strani porečja. V porečju Kamniške Bistrice je 791,2 km vodnih tokov in z gostoto $1,49 \mathrm{~km} / \mathrm{km}^{2}$ se uvršča med porečja $\mathrm{z}$ nadpovprečno gosto rečno mrežo glede na slovensko povprečje, ki znaša $1,33 \mathrm{~km} / \mathrm{km}^{2}$ (Kolbezen idr., 1998) oziroma 1,4 km/ $\mathrm{km}^{2}$ (Vodno..., 2003). V zgornjem delu porečja gostota stalnih vodnih tokov ne presega $1 \mathrm{~km} / \mathrm{km}^{2}$, zelo majhna pa je tudi v porečju Pšate, kjer znaša pod $1 \mathrm{~km}$ stalnih vodnih tokov na $\mathrm{km}^{2}$. Gostota vodnih tokov v porečju Kamniške Bistrice je glede na zakraselost zgornjega dela porečja in prepustne kamnine $\mathrm{v}$ spodnjem delu večja, kot bi pričakovali. Nedvomno na večjo gostoto vodnih tokov v porečju pomembno vplivajo mlinščice, ki spremljajo večino srednjega in spodnjega toka reke, med Homcem in Domžalami celo na obeh straneh reke. Kot posledica reliefnih značilnosti je za zgornji tok Kamniške Bistrice značilen velik strmec, ki na odseku od izvira do Stahovice presega $23 \%$. To se odraža v veliki erozijski moči vodnega toka, koritasto oblikovani strugi in, ob zmanjšanju strmca, v intenzivnem odlaganju rečnega gradiva. Strmec toka se opazno zmanjša na odseku od Stahovice do Kamnika, kjer ne presega $11 \%$, to pa je tudi srednji strmec celotnega toka. Že pri Stahovici je rečno korito širše in plitvejše, na dnu in ob brežinah je veliko odloženega gradiva, izoblikovana je obrežna ravnica in manjše terase. Od Kamnika do izliva v Savo je struga Kamniške Bistrice zelo široka in ob nizkem vodostaju vodni tok ni enoten. To je posledica regulacij in povečevanja pretočnih zmogljivosti struge zaradi varovanja naselij pred poplavami. V dnu struge so številni pragovi, večji jezovi pa so na odsekih, kjer se od toka reke odcepijo mlinščice npr. pri Homcu, Radomljah in Ihanu. Med večjimi pritoki imata največji srednji relativni strmec vodnega toka Črna in Nevljica, najmanjšega pa Rača in Pšata (Brečko Grubar, 2006).

Za vodomerno postajo Kamnik I je med vsemi tremi vodomernimi postajami zabeležena največja količina padavin, najmanjše izhlapevanje in največji odtok padavin. Odtočni količnik je kljub temu, da vodomerna postaja »obsega« tudi Nevljico, opazno višji v primerjavi z vodomernima postajama Nevlje I in Podrečje. Odtočna količnika, prvi je dobljen na osnovi členov vodne bilance, drugi pa na osnovi izmerjenih padavin in pretokov, se opazno razlikujeta le pri Nevljici, kjer dejansko odteče manj vode (Kolbezen idr., 1998). Na manjši odtok padavin v hribovitem delu porečja Kamniške Bistrice v primerjavi z zgornjim delom vplivajo, po našem mnenju, manjši relativni relief in nakloni, manjši strmci vodnih tokov, večja pokritost $\mathrm{z}$ gozdom ter zadrževanje padavin v prsti. V spodnjem delu porečja je višina odtoka glede na reliefne značilnosti, strmce vodnih tokov, manjšo gozdnatost in prepustno kamninsko zgradbo še manjša. Iz jugovzhodnega dela porečja naj bi odteklo od 49 do $50 \%$ padavin, to je okoli $600 \mathrm{~mm}$, iz jugozahodnega dela, ki pripada porečju Pšate, pa samo 30 \% padavin (Kolbezen idr., 1998). 
Preglednica 1: Strmci vodnih tokov v porečju Kamniške Bistrice

Table 1: Vertical drops of streams in the Kamniška Bistrica drainage basin

\begin{tabular}{|c|c|c|c|}
\hline Odsek vodnega toka & $\begin{array}{c}\text { Nadmorska višina } \\
\text { zgornje in spodnje } \\
\text { točke odseka (m) }\end{array}$ & $\begin{array}{l}\text { Dolžina vodnega toka } \\
\qquad(\mathrm{km})\end{array}$ & $\begin{array}{l}\text { Relativni strmec na } \\
\text { odseku (\%) }\end{array}$ \\
\hline $\begin{array}{l}\text { izvir Kamniške Bistrice-Stahovica } \\
\text { (izliv Črne) }\end{array}$ & $630-427$ & 8,5 & 23,9 \\
\hline Stahovica-Kamnik (izliv Nevljice) & $427-375$ & 4,5 & 11,6 \\
\hline Kamnik-Domžale (izliv Rače) & $375-300$ & 10,5 & 7,1 \\
\hline Domžale-izliv v Savo & $300-264$ & 8,5 & 4,2 \\
\hline Kamnik-izliv & $375-264$ & 19,0 & 5,8 \\
\hline Kamniška Bistrica izvir-izliv & $630-264$ & 32,0 & 11,4 \\
\hline Črna izvir-izliv & $900-427$ & 8,0 & 59,1 \\
\hline Nevljica izvir-izliv & $800-375$ & 17,5 & 24,3 \\
\hline Rača izvir-izliv & $380-300$ & 13,5 & 5,9 \\
\hline Rača izvir-Zalog pod Sv. Trojico & $380-320$ & 7,0 & 8,6 \\
\hline Rača Zalog pod Sv. Trojico-izliv & $320-300$ & 6,5 & 3,1 \\
\hline Radomlja izvir-izliv & $580-305$ & 21,5 & 12,8 \\
\hline Radomlja izvir-Imovica & $580-320$ & 16,5 & 15,8 \\
\hline Radomlja Imovica-izliv v Račo & $320-305$ & 5,0 & 3,0 \\
\hline Pšata izvir-izliv & $400-270$ & 24,0 & 5,4 \\
\hline Pšata izvir-Moste & $400-330$ & 10,0 & 7,0 \\
\hline Pšata Moste-izliv & $330-270$ & 14,0 & 4,3 \\
\hline
\end{tabular}

Vir: Državna..., 1996a; Državna..., 1996b; Državna..., 1996c; Državna..., 1996d; Državna..., 1998a;

Državna..., 1998b; Državna..., 1998c; Državna..., 1998d.

Preglednica 2: Vodna bilanca vodozbirnih zaledij treh vodomernih postaj v porečju Kamniške Bistrice v obdobju 1961-1990

Table 2: Water balance in the catchment areas of three water-gauging posts in the Kamniška Bistrica drainage basin in the 1961-1990 period

\begin{tabular}{|l|c|c|c|c|c|c|}
\hline Vodni tok & $\begin{array}{c}\text { Vodomerna } \\
\text { postaja }\end{array}$ & $\begin{array}{c}\text { Padavine } \\
(\mathrm{mm})\end{array}$ & $\begin{array}{c}\text { Izhlapevanje } \\
(\mathrm{mm})\end{array}$ & Odtok (mm) & $\begin{array}{c}\text { Odtočni } \\
\text { količnik } \\
-\mathrm{KK}(\%)^{1}\end{array}$ & $\begin{array}{c}\text { Odtočni } \\
\text { količnik } \\
- \text { HK }(\%)^{2}\end{array}$ \\
\hline Kamniška Bistrica & Kamnik I & 1756 & 587 & 1169 & 66,6 & 68,2 \\
\hline Nevljica & Nevlje I & 1491 & 633 & 858 & 57,6 & 46,2 \\
\hline Rača & Podrečje & 1336 & 633 & 672 & 50,3 & 49,9 \\
\hline
\end{tabular}

${ }^{1}$ klimatski odtočni količnik, dobljen na osnovi členov vodne bilance (padavin, izhlapevanja in odtokov)

${ }^{2}$ hidrološki odtočni količnik, dobljen na osnovi padavin in izmerjenih pretokov

Vir: Kolbezen idr., 1998. 
Vloga naravnogeografskih značilnosti porečja pri sonaravnem upravljanju ...

Preglednica 3: Moduli odtoka za vodomerne postaje v porečju Kamniške Bistrice

Table 3: Discharge modules for water-gauging posts in the Kamniška Bistrica drainage basin

\begin{tabular}{|c|c|c|c|c|c|c|c|c|c|c|c|c|}
\hline v. $p$ & jan & feb & mar & apr & maj & jun & jul & avg & sept & okt & nov & dec \\
\hline 1 & 0,70 & 0,68 & 1,05 & 1,06 & 1,38 & 1,41 & 1,06 & 0,71 & 0,82 & 1,09 & 1,33 & 0,95 \\
\hline 2 & 0,62 & 0,44 & 0,59 & 0,91 & 1,33 & 1,31 & 1,10 & 0,47 & 0,73 & 1,68 & 1,98 & 0,98 \\
\hline 3 & 0,95 & 0,90 & 1,08 & 1,19 & 0,97 & 1,01 & 0,87 & 0,64 & 0,82 & 1,11 & 1,51 & 1,22 \\
\hline 4 & 0,92 & 0,98 & 1,05 & 1,11 & 0,94 & 0,97 & 0,89 & 0,82 & 0,87 & 0,97 & 1,29 & 1,18 \\
\hline 5 & 0,97 & 1,16 & 1,15 & 1,22 & 0,87 & 0,97 & 0,78 & 0,61 & 0,80 & 1,02 & 1,22 & 1.23 \\
\hline 6 & 0,85 & 0,68 & 0,83 & 0,94 & 0,68 & 0,69 & 0,70 & 0,65 & 0,89 & 1,44 & 2,18 & 1,50 \\
\hline
\end{tabular}

1 Kamniška Bistrica - Kamnik I (1946 - 2000)

2 Kamniška Bistrica - Vir (1978 - 80, 1991 - 2000)

3 Nevljica - Nevlje I (1959-2000)

4 Rača-Podrečje (1957 - 72, 1981, 1983 - 97, 1999-2000)

5 Pšata-Moste I (1956-68, 1970-84, 1986-89)

6 Pšata-Topole $(1989-2000)$

Op.: poudarjene so največje vrednosti modulov odtoka

Vir: Arhiv ARSO; Hidrološki letopis..., 1995 - 2006.

Pretočne vrednosti Kamniške Bistrice na vodomerni postaji Kamnik I kažejo značilnosti snežno-dežnega pretočnega režima z nadpovprečnimi pretoki od marca do julija ter v oktobru in novembru. Pretoki pod srednjo letno vrednostjo v decembru, januarju in februarju predstavljajo zimski nižek, ki je izrazitejši od poletnega v avgustu in septembru. $\mathrm{Na}$ pretočne vrednosti reke na vodomerni postaji Kamnik I pomembno vpliva relief z velikimi nadmorskimi višinami in dalj časa trajajočo snežno odejo, velika količina padavin tudi v topli polovici leta, kraške kamnine in podzemno pretakanje voda, vplivajo pa tudi pretoki Nevljice, kjer podatki vodomerne postaje Nevlje I kažejo značilnosti dežno-snežnega pretočnega režima. Pretočne značilnosti Kamniške Bistrice na vodomerni postaji Vir kaže 14-letni niz podatkov, kar je prekratko obdobje za ugotavljanje značilnosti. Na značilnosti pretočnega režima tu pomembno vpliva prepustnost kamnin in pronicanje rečne vode $\mathrm{v}$ podtalnico, kar znižuje pretočne vrednosti spomladi. Poleg tega je močno zmanjšan vpliv visokogorja in $\mathrm{z}$ nadmorsko višino pogojene snežne retinence, izrazitejši pa je vpliv dežnih padavin v jeseni. Upoštevati moramo še antropogeni vpliv odvzema vode in pretakanja rečne vode po mlinščicah. Pretočni režim Rače na vodomerni postaji Podrečje je primerljiv s pretočnim režimom Nevljice. Pretočne vrednosti za Pšato na vodomerni postaji Moste I kažejo sicer nekoliko drugačne značilnosti, Pšato pa prav tako kot Nevljico, Račo in Kamniško Bistrico na Viru uvrščamo v tip dežno-snežnega pretočnega režima. Na njen pretočni režim vplivajo pritoki z različno dinamiko, tisti s Tunjiškega gričevja imajo drugačne značilnosti od Pšate v povirnem delu, katere porečje sega na Krvavec in je deloma zakraselo, zopet drugačne so pretočne značilnosti Reke ali Brnika, ki priteka s Kranjskega polja. Pretočne vrednosti za Pšato na vodomerni postaji Topole imamo za 12-letno obdobje, kar je za določanje pretočnega režima malo, kažejo pa zanimivo dinamiko reke. 
Pri upravljanju z vodnimi viri je pomembna količina vodnih virov, zlasti ob nizkih vodnih stanjih. Kot pomembna pokazatelja količine vodnih virov smatramo tudi specifični odtok porečja in srednji letni pretok reke. V porečju Kamniške Bistrice obstojijo precejšnje razlike v specifičnem odtoku med vodozbirnimi zaledji vodomernih postaj. Po navedbah vira je specifični odtok, dobljen na osnovi izmerjenih pretokov v obdobju 1961-1990, za vodozbirno zaledje vodomerne postaje Kamnik I znašal $38 \mathrm{l} / \mathrm{s} \mathrm{km} \mathrm{km}^{2}$ in specifični odtok, dobljen na osnovi izračunanih pretokov, 37,1 1/s km². Specifični odtoki za vodozbirno zaledje vodomerne postaje Nevlje I na Nevljici znašajo v istem obdobju $21,81 / \mathrm{s} \mathrm{km}^{2}$ (izračunani pretok) oziroma 27,2 l/s km² (izmerjeni pretok), za vodozbirno zaledje vodomerne postaje Podrečje na Rači pa 21,2 1/s km² (izračunani pretok) oziroma 21,3 1/s km² (izmerjeni pretok) (Kolbezen idr., 1998). Ker vodomerna postaja Kamnik I že vključuje Nevljico, nas pa je zanimal specifični odtok $\mathrm{v}$ zgornjem delu porečja nad Kamnikom in pritokom Nevljico, smo vrednost srednjega letnega pretoka za Nevljico odšteli in dobili specifični odtok 51,4 1/s km${ }^{2}$, ki je precej višji od zgoraj navedenega. Izračunali smo srednja letna specifična odtoka za porečje Kamniške Bistrice nad vodomerno postajo Vir, ki je v obdobju 1978-2000 znašal $26,131 / \mathrm{s} \mathrm{km}^{2}$ in nad vodomerno postajo Domžale, ki je v obdobju 1978-1991 znašal 27,63 $1 / \mathrm{sm}^{2}$. V porečju Radomlje sta $\mathrm{v} 60$. letih prejšnjega stoletja delovali vodomerni postaji Trnjava in Trnjava I, prva nad izlivom Drtijščice v Radomljo in druga pod njim. Srednja letna specifična odtoka sta znašala 25 in $23,9 \mathrm{l} / \mathrm{s} \mathrm{km}^{2}$. Na osnovi podatkov za vodomerni postaji na Pšati smo izračunali srednji letni specifični odtok njenega porečja. Za porečje nad vodomerno postajo Moste I je v obdobju 1956-1989 znašal 17,8 1/s km² in nad vodomerno postajo Topole v obdobju 1989-2000 le 13,9 1/s km².

Srednji letni pretok Kamniške Bistrice na vodomerni postaji Kamnik I je v obdobju 1946-2000 znašal 7,56 m³/s, na Viru v obdobju 1978-2000 5,43 m³ $/ \mathrm{s}$ in v Domžalah v obdobju 1978-1991 10,3 m³/s. »Primanjkljaj« v rečnem pretoku na Viru v primerjavi s Kamnikom je posledica pretakanja rečne vode po mlinščicah in verjetno tudi ponikanja rečne vode $\mathrm{v}$ podzemni vodonosnik. Na izlivu Kamniške Bistrice naj bi po ocenah za obdobje pred letom 1970 znašal srednji letni pretok $20,9 \mathrm{~m}^{3} / \mathrm{s}$, srednji letni nizki pretok $3,75 \mathrm{~m}^{3} / \mathrm{s}$, najnižji pretok $1,95 \mathrm{~m}^{3} / \mathrm{s}$ in najvišji pretok $240 \mathrm{~m}^{3} / \mathrm{s}$ (Vodnogospodarske..., 1978). Srednji letni pretok Rače na vodomerni postaji Podrečje je v obdobju 1961-2000 znašal 5,6 m³ $/ \mathrm{s}$ in Pšate na vodomerni postaji Moste I v obdobju 1956-1989 1,4 m³/s (arhiv ARSO). Razmerje med srednjim nizkim, srednjim in srednjim visokim pretokom v obdobju kaže največje kolebanje pretokov Pšate na vodomerni postaji Moste $(1: 7: 76,6)$, še večje je na vodomerni postaji Topole, vendar moramo upoštevati, da so regulacije vodnih tokov močno spremenile odtočne značilnosti. Razmerje med najmanjšim in največjim zabeleženim pretokom v obdobju delovanja vodomerne postaje je $1: 1040$. Veliko kolebanje pretokov kažejo tudi podatki za vodomerno postajo Nevlje I, kjer je razmerje med srednjim nizkim, srednjim in srednjim visokim pretokom v obdobju 1 $: 5,3: 60$, razmerje med izjemnima pretokoma pa $1: 717$. Manjše kolebanje pretokov kažejo podatki za Račo na vodomerni postaji Podrečje $(1: 4: 26,8)$, kjer na pretočne značilnosti vpliva dotok mlinščice. Razmerje med izjemnima pretokoma na vodomerni postaji Podrečje je $1: 526$. Za Kamniško Bistrico na vodomerni postaji Kamnik I je razmerje med srednjim nizkim, srednjim in srednjim visokim pretokom $\mathrm{v}$ obdobju $1: 3,6: 29,8$ ter med izjemnima pretokoma $1: 324$ (Brečko Grubar, 2006). 
Vodni odtok v porečju in kamninska zgradba, predvsem prepustnost in poroznost kamnin pogojujeta, poleg zalog vode v površinskih vodnih tokovih, tudi zaloge podzemnih voda. V porečju Kamniške Bistrice se v večjem obsegu nahajata dva tipa vodonosnikov, to je kraško-razpoklinski in medzrnski. Prvi tip vodonosnika je značilen za trde kamnine, ki so razpokane ali korozijsko izvotljene in se v večjem obsegu nahajajo v zgornjem delu porečja Kamniške Bistrice. Njihova skupna izdatnost je velika, kar je posledica velike količine padavin in hitrega podzemnega pretakanja. Deloma zakraseli sta tudi porečji Rače in Drtijščice, predvsem njihovi levi strani, ki segata do razvodnega slemena s Savo. V spodnjem delu porečja pa je kraško območju Rašice, od koder pritekata pritoka Pšate Blatnica in Motnica in območje Brda pri Ihanu. Medzrnski tip vodonosnika se je izoblikoval v nesprijetih ali deloma sprijetih sedimentnih kamninah na Kamniškobistriški ravnini. Njegova izdatnost je pogojena $\mathrm{z}$ dotoki padavin in rečne vode, s hitrostjo pretakanja podzemne vode in s poroznosti kamnine. Kamniškobistriško ravnino gradijo večinoma grobo zrnati rečno-ledeniški nanosi Kamniške Bistrice, kar je ugodno za izdatnost vodnega vira. V manjšem obsegu so v porečju zastopani še razpoklinski vodonosniki manjše izdatnosti in medzrnski vodonosniki manjše izdatnosti. Prvi se pojavljajo v slabše prepustnih, manj razpokanih kamninah, drugi pa v dnu dolin, kjer prevladujejo drobno zrnati glineno-ilovnati sedimenti (Hidrogeologija..., 2005).

V porečju Kamniške Bistrice so najbogatejši viri podzemnih voda večinoma zajeti. $\mathrm{V}$ zgornjem delu porečja Kamniške Bistrice se takšen vodni vir nahaja na levem bregu Kamniške Bistrice nad Stahovico, kjer je drenažno zajetje Iverje in na območju Krvavca, kjer pitno vodo črpajo iz več vrtin. Za oskrbo naselij so v zgornjem delu porečja zajeti nekateri manj izdatni izviri, evidentirani izdatni in še neizkoriščeni vodni viri pa se nahajajo ob pritokih Korošici, Konjski, Kamniški Beli. Po naši oceni navedeni podzemni vodni viri v zgornjem delu porečja presegajo $0,6 \mathrm{~m}^{3} / \mathrm{s}$. Izdatni vodni vir v porečju Kamniške Bistrice je podzemna voda $\mathrm{v}$ razpoklinskem vodonosniku na območju Kolovca, ki se nahaja severovzhodno od Volčjega Potoka in napaja vodovodni sistem Domžale. Območje Kolovca je gozdnato in neposeljeno, na njegovem obrobju pa se nahajajo še številna manjša zajetja za oskrbo naselij (interno gradivo JKP Prodnik). V porečju Nevljice se nahaja veliko izvirov z majhno izdatnostjo, ki s pitno vodo oskrbujejo posamezna naselja, najbolj poznani so izviri Snoviščice. Več izvirov s pretokom nekaj 1/s je v porečju Rače, v dolini Črnega grabna in v hribovju severno od njega, bogatejši pa so nekateri izviri v Moravški dolini, katerih pretok presega 10 l/s (Vodnogospodarska..., 2002). V spodnjem delu porečja je za oskrbo vodovodnega sistema Domžale zajeta podtalnica na Kamniškobistriški ravnini in podzemna voda iz razpoklinskega (dolomitnega) vodonosnika pod prodnim vodonosnikom. Dinamična izdatnost vodonosnika Kamniškobistriške ravnine je bila ocenjena na okoli $0,5 \mathrm{~m}^{3} / \mathrm{s}$ (Vodnogospodarska..., 2002).

\section{SKLEP}

Naravnogeografske značilnosti in njihova raznolikost v porečju Kamniške Bistrice sta vzrok različnim oblikam vodnih virov v porečju, različni dinamiki in različni pokrajinski občutljivosti vodnih virov, ki so pomembni dejavniki pri načrtovanju sonaravnega upravljanja 
$\mathrm{z}$ vodnimi viri. Razumljivo se $\mathrm{v}$ ospredje postavlja količinski vidik oziroma izdatnost vodnih virov, ki določa razpoložljivo količino vode $\mathrm{v}$ določenem obdobju. Zaradi intenzivne pokrajinske rabe in njenega negativnega vpliva na stanje okolja, pa postajata vse bolj pomembna tudi kakovost vodnih virov in ohranjenost ekosistemov vodnega in obvodnega prostora. V goratem zgornjem delu porečja Kamniške Bistrice so prisotni različno izdatni kraški izviri, ki so občutljivi za onesnaženje, vendar naravnogeografske značilnosti (nadmorske višine, nakloni) njihovih zaledij ne omogočajo intenzivnejše pokrajinske rabe. Kamniška Bistrica ima izrazito hudourniški značaj in ob visokih vodnih stanjih stopnjuje naravno ogroženost okolja. V hribovitem delu porečja so z različno kamninsko zgradbo in lego pogojeni različno izdatni podzemni vodni viri. Večina jih ima majhen ali spremenljiv pretok in so $\mathrm{z}$ vodno gospodarskega vidika manj pomembni. Pokrajinska raba je v primerjavi z goratim delom porečja bolj intenzivna, kar povečuje njihovo izpostavljenost onesnaževanju in spreminjanje hidrografskih značilnosti vodnih tokov. Slednjemu smo priča zlasti pri Radomlji, Rači in Pšati, kjer so bili zaradi prometne infrastrukture, kmetijske rabe zemljišč, poselitve in varnosti pred poplavami izvedeni regulacijski in hidromelioracijski posegi. Ekosistemi vodnega in obvodnega prostora so bili v veliki meri uničeni, pritiski na vodno okolje pa se stopnjujejo. Navedeni površinski vodni tokovi imajo zelo spremenljiv vodni pretok in so zlasti ob poletnem nizkem stanju zelo občutljivi za onesnaževanje okolja. $\mathrm{V}$ spodnjem delu porečja sta vodnogospodarsko najpomembnejša vira podtalnica in površinski vodni tok reke. Podtalnica je kot vir pitne vode $\mathrm{z}$ večino svoje izdatnosti vključena v oskrbo, Kamniška Bistrica pa je bila v preteklosti pomemben vir energije in tehnološke vode. $Z$ jezovi in pretočitvami $\mathrm{v}$ mlinščice je bil močno spremenjen vodni odtok in povečana pokrajinska občutljivost reke. Danes je Kamniška Bistrica v spodnjem toku predvsem prejemnik delno očiščenih odpadnih vod večine prebivalstva in dejavnosti na območju Kamnika, Domžal, Mengša in Trzina ter nezajetih odpadnih vod. Kamniška Bistrica ima precej spremenljiv pretok in je ob visokih vodnih stanjih v spodnjem delu porečja pogosto poplavljala. Zaradi zagotavljanja varnosti naselij so bile izvedene obsežne regulacije, ki so dodatno spremenile vodni tok in trajno zmanjšale samočistilno sposobnost vodnega okolja, izjemno visoka vodna stanja pa še danes ogrožajo nekatera naselja kot so Ihan, Videm, Dolsko idr. Na Kamniškobistriški ravnini je pokrajinska raba zelo intenzivna, kar nam kaže že nizek delež gozdnih površin. Prevladujejo obdelovalna in pozidana zemljišča, ki so se razširila tudi na nekdanja območja zadrževanja poplavnih vod. Intenzivna raba zemljišč je vzrok onesnaženosti podtalnice, ki je pred vplivi s površja slabo zavarovana in v spodnjem delu območja plitvo pod površjem. Območje s podtalnico bi lahko označili kot pokrajinsko zelo občutljivo. S poznavanjem naravnogeografskih značilnosti porečja kot so relief, kamninska zgradba, podnebne in vegetacijske značilnosti ter $\mathrm{z}$ njimi povezanimi hidrografskimi značilnostmi je mogoče oceniti pokrajinsko občutljivost okolja vodnih virov in temu prilagoditi obremenjevanje okolja. Sonaravno upravljanje z vodnimi viri naj bi, po našem mnenju, vzpostavilo ravnovesje med njima in tako omogočilo trajno rabo vodnih virov in obstoj ekosistemov, ki so odvisni od vode in zelo pomembni za kakovost okolja. 


\section{Viri in literatura}

Podatki o vodostajih in pretokih rek na vodomernih postajah. Arhiv ARSO. Ljubljana,

Ministrstvo za okolje in prostor R Slovenije.

Brečko Grubar, V., 2005. Vodna učna pot z vidika geografije - porečje Kamniške Bistrice.

Slovenija - vodna učna pot Evrope. Ljubljana, Filozofska fakulteta, Oddelek za

geografijo, 109 str.

Brečko Grubar, V., 2006. Trajnostno sonaravno gospodarjenje z vodnimi viri v porečju

Kamniške Bistrice : doktorska disertacija. Ljubljana, Filozofska fakulteta, Oddelek za geografijo, 170 str.

Corine land cover. 1998. Ljubljana, Ministrstvo za okolje in prostor, Geodetska uprava RS.

Dejanska raba kmetijskih zemljišč (Raba_beta_20050408). 2006. Ljubljana, Ministrstvo za kmetijstvo gozdarstvo in prehrano.

Downs, P. W, K. J. Gregory, 2000. River Channel Management. Towards Sustainable Catchment Hydrosystems. London, Arnold, A member of the Hadder Headline Group.

Državna topografska karta RS 1:25.000. 072, Cerklje. 1998a. 1. izd. 1:25.000. Ljubljana, MOP, Geodetska uprava RS.

Državna topografska karta RS 1:25.000. 117, Dolsko. 1996a. 1. izd. 1:25.000. Ljubljana, MOP, Geodetska uprava RS.

Državna topografska karta RS 1:25.000. 96, Kamnik. 1996b. 1. izd. 1:25.000. Ljubljana, MOP, Geodetska uprava RS.

Državna topografska karta RS 1:25.000. 73, Kamniška Bistrica. 1998b. 1. izd. 1:25.000. Ljubljana, MOP, Geodetska uprava RS.

Državna topografska karta RS 1:25.000. 074, Luče. 1998c. 1. izd. 1:25.000. Ljubljana, MOP, Geodetska uprava RS.

Državna topografska karta RS 1:25.000. 116, Ljubljana. 1996c. 1. izd. 1:25.000. Ljubljana, MOP, Geodetska uprava RS.

Državna topografska karta RS 1:25.000. 095, Medvode. 1996d. 1. izd. 1:25.000. Ljubljana, MOP, Geodetska uprava RS.

Državna topografska karta RS 1:25.000. 97, Moravče. 1998d. 1. izd. 1:25.000. Ljubljana, MOP, Geodetska uprava RS.

Geografski atlas Slovenije : država v prostoru in času. 1998. Ljubljana, DZS, 360 str.

Hidrogeologija. URL: http://kremen.arso.gov.si/Nvatlas (citirano 7. 12 2005)

Hidrološki letopis Slovenije 1990-2002. 1995-2006. Ljubljana, MOP RS, Hidrometeorološki zavod R Slovenije (Agencija RS za okolje).

Integrirano gospodarjenje $\mathrm{z}$ vodnimi viri. 2000. GWP-TAC publikacije, 4. Ljubljana, 60 str.

Interaktivni atlas Slovenije. 1998. Ljubljana, Geodetski zavod Slovenije, Mladinska knjiga. CD-ROM.

Kmetijska raba tal po katastrskih občinah 1999. Ljubljana. Ministrstvo za okolje in prostor RS. Geodetska uprava RS.

Klimatografija Slovenije. 1995. Temperature zraka: obdobje 1961-1990. Ljubljana, Hidrometeorološki zavod RS, 356 str. 
Klimatografija Slovenije. 1995. Količina padavin: obdobje 1961-1990. Ljubljana, Hidrometeorološki zavod RS, 366 str.

Kolbezen, M., J. Pristov, 1998. Površinski vodotoki in vodna bilanca Slovenije. Ljubljana, Hidrometeorološki zavod R Slovenije, 98 str.

Krvavški in kamniški vodovodni sistem ter dolgoročna oskrba z vodo. 2000. Raziskovalna naloga. Ljubljana, IMOS GEA d.o.o., 93 str.

Morris, P., J. Briggs, 1995. Water. Methods of Environmental Impact Assesment (ur. P. Morris, R, Therivel). London, UCL Press, str. 161- 196.

Nacionalni program varstva okolja. URL: http://www.npvo.si/osnutek/celoten_dokument.pdf

Načrt urejanja povodja - Vodnogospodarsko načrtovanje v okvirih približevanja Evropski uniji. 1998. Načrt urejanja povodja Kokre. Lidija Globevnik (ur.). Ljubljana, MOP, Uprava RS za varstvo narave, 103 str.

Novak, D., 1993. Hidrogeološki kataster - občina Kamnik. Kataster vodnih virov. Ljubljana, GZL.

Osnovna geološka karta SFRJ. L 33-66, Ljubljana. 1982. 1:100.000. Beograd, Zvezni geološki zavod.

Peets, G., J. Bravard, 1996. A Drenage Basin Perspective, Fluvial Hydrosystems. London, Chapman and Hall, str.13-36.

Plut, D., 2000. Geografija vodnih virov. Ljubljana, Filozofska fakulteta, Oddelek za geografijo, 281 str.

Radinja, D., 1999. Hidrogeografska terminologija (delovno gradivo). Ljubljana, 42 str.

Študija ranljivosti okolja. 2002. Špes, M. (ur.). Ljubljana, ZRC. (Geografica Slovenica, 35/1-2, $150 \mathrm{str}$.)

Vodno bogastvo Slovenije, 2003. Ljubljana, Ministrstvo za okolje in prostor R Slovenije

Vodnogospodarske osnove Slovenije, 1978. Ljubljana, Zveza vodnih skupnosti in VGP Maribor.

Vodnogospodarska osnova povodja Kamniške Bistrice. 2002. Ljubljana, Vodnogospodarski inštitut, družba za gospodarjenje z vodami d. o. o.

Zakon o vodah. 2002. URL: http://www.gov.si/mpo/zakonodaja/zakoni/okolje/voda/vode pdf (citirano 27. 11. 03)

\section{THE ROLE OF NATURAL-GEOGRAPHICAL CHARACTERISTICS OF THE DRAINAGE BASIN IN THE SUSTAINABLE MANAGEMENT OF WATER RESOURCES IN THE KAMNIŠKA BISTRICA DRAINAGE BASIN}

\section{Summary}

Sustainable management of water resources is understood as a way of managing water resources that will make possible the qualitative and reliable water supply also in the future and will provide the existence and operation of water-related ecosystems. Management of water resources planned in such a way should to the greatest possible extent 
take account of the characteristics, laws, capacities (i.e. limitations) of the environment of water resources and ecosystems which make this environment. Drainage basin as an open hydrological system is a convenient spatial unit for the planning of sustainable management of water resources, since it represents a rounded off whole, the constituents of which are interconnected surface- and ground-waters and water resources. In addition to the surface streams in the Kamniška Bistrica drainage basin, there are also diverse underground water resources. Because of the specific geographical characteristics of the drainage basin and its parts (upper and lower sections of the drainage basin, drainage basins of tributaries), these water resources differ in abundance and in landscape sensitivity. Important underground karst waters occur in the upper section of the drainage basin, while in the lower section, there are groundwater and surface streams, both of the Kamniška Bistrica and its tributaries. The sustainable management of water resources in the Kamniška Bistrica drainage basin requires the knowledge about natural-geographical characteristics of the environments of water resources, such as precipitation, landforms, rock structure, woodiness, etc., since they influence the hydrologic characteristics, especially those of the runoff. Discussed are the natural-geographical characteristics of the Kamniška Bistrica drainage basin in relation to the characteristics of the drainage network, aquifers and the dynamism of water resources. The upper section of the Kamniška Bistrica drainage basin above Kamnik is characterised by mountains, karst and large amount of annual precipitation, which results in nival-pluvial discharge regime, high run-off, torrential characteristics of the river and underground water flows. The greatest portion of the drainage basin area belongs to mountains with diverse rock structure and, if compared to its upper section, smaller amount of precipitation. Prevailing is the surface runoff of precipitation, which is manifested in the high density of drainage network. The surface streams have pluvial-nival discharge regime, minimum discharges in summer, and torrential character. The underground water sources are mainly less abundant or even impermanent. Prevailing in the level lower section of the drainage basin are fluvialglacial sediment rocks, in which important reserves of groundwater are stored. The surface streams have but little vertical drops and, in comparison with the already described two sections, higher discharges which show the characteristics of pluvial-nival discharge regime. Water streams are mainly transformed due to hydro-meliorations, industrial use of water and protection against floods. The ecosystems of aquatic world and of environments temporarily under water (flood retention areas, river banks, etc.) are mainly degraded.

Natural-geographical characteristics of the Kamniška Bistrica drainage basin should, according to our opinion, act as a point of departure for the sustainable planning of water resources managing in the drainage basin and should be included into the Plan of the Management of Drainage Basin when it is going to be made. 